\title{
Assessment of Plant Materials Carbon Sequestration Rate for Horizontal and Vertical Landscape Design
}

\author{
Rashidi Othman and Siti Zubaidah Abu Kasim
}

\begin{abstract}
The excessive reliance of fossil fuels and carbon production from daily appliances especially in tourism accommodation premises could cause detrimental impact to the surrounding environment. This is due to the increase of carbon emissions which is one of the major contributors for greenhouse effect especially in urban area. In order to alleviate the carbon footprint by those premises, one of the promising method to reduce carbon dioxide emission to the atmosphere is by selecting an appropriate plant species as well as optimization of spatial organization of plant materials. Besides character of the plant materials, criteria such as locality, age, diameter and height are very much influenced the carbon sequestration rate. This study demonstrate that even with limited green space areas for tourism accommodation premises such as hotels and resorts, the carbon sequestration rate can be further increased with the right selection of plants, at the right place with the right landscape design. Therefore this study aimed to monitor, calculate and predict how much carbon can be absorbed by proposed plant species based on vertical and horizontal landscape design at certain period of time. The significance outcomes of this study will be green approach to monitor and sequester carbon toxicity using plant species also a novel landscape design approach to neutralize carbon emission which is cost effective and environmental friendly.
\end{abstract}

Index Terms-Carbon footprint, green space, carbon sequestration rate, vertical landscape design, horizontal landscape design, green technology.

\section{INTRODUCTION}

Since the late 19th century, carbon dioxide gas in the atmosphere has increased 25\% [1]. While Hussain et al. [2] has highlighted that the carbon dioxide atmospheric concentration has risen to $35 \%$ from year 1870 to 2005 due to the dynamic development of industry sectors such as mining, energy, and manufacturing. In order to reduce this issue, [3] highlighted that carbon sequestration has been suggested as a mean to help mitigate the increase in atmospheric carbon dioxide concentration. This technology can limit the carbon dioxide gas from entering the atmosphere and later on can heading to low concentration of carbon dioxide gas through the rate of time.

Towards the 20th century onwards, the human populations are also increasing over the world not excluded in Malaysia. According to the Department of Statistics, Malaysia's

Manucript received May 20, 2015; revised August 4, 2015. This work was supported by Ministry of Education research grants FRGS 13-052-0293, RACE 14-002-0008 and NRGS 13-002-0002.

The authors are with the International Institute for Halal Research and Training (INHART), Herbarium Unit, Department of Landscape Architecture, Kulliyyah of Architecture and Environmental Design (KAED), International Islamic University Malaysia, 53100 Kuala Lumpur, Malaysia (e-mail: rashidi@iium.edu.my, sitizubaidah_ak@yahoo.com). population grew by a third since 1991 to reach 24.5 million inhabitants by the end of 2002 [4]. This statement only to illustrate how many people increased from year to year and from decade to decade. Referring to Sahabat Alam Malaysia [4], the Federal Territory contained over 6,000 city dwellers per $\mathrm{km}^{2}$, Penang had 1,348 people per $\mathrm{km}^{2}$, and Melaka has 408 people per $\mathrm{km}^{2}$. In a 20 -year period, the urban masses almost doubled from a $27 \%$ share to a $51 \%$ share of the population. Alternative ways that have been further studied to reduce these greenhouse effects in the atmosphere is through carbon sequestration technology [5].

Carbon sequestration is defined as a method or a process of moderating carbon dioxide in the atmosphere to stop it from being polluted [6]. Singh [6] further highlighted that as the name carbon sequestration suggested, carbon dioxide emitted from thermal power plants and carbon dioxide intensive industries is captured and stored in various reservoirs to lessen their polluting impact on the atmosphere. This method will contribute to mitigate global warming as it will capture and store carbon dioxide gas in particular processes [7]. The processes includes capturing carbon dioxide that have been emitted, storing and absorbing it in a specific platform and then releasing the carbon dioxide gas with low concentration [8]. Terrestrial carbon sequestrations are methods which the carbon will be absorbed by the plant materials naturally [9]. In this case, plant materials are the platform for the carbon to be captured and absorbed, also known as biological sequestration. The largest net uptake for biological sequestration is due to the ongoing natural regrowth of forests that were harvested during the 19th and early 20th centuries [10]. It shows that plant materials play important roles to store the carbon that exist at the atmosphere. Thus, this study aimed to evaluate the carbon sequestration rate at the tourism premises that lead to calculate, monitor and predict how much carbon can be absorbed by existing plant species at certain period of time. The first step is to identify the built up area and green area of the selected tourism premises, then to calculate the carbon sequestration rate occurred and finally to recommend strategies and approaches to achieve an optimum carbon sequestration rate to be implemented in a tourism accommodation premises. The case study for the research is differentiated between two characters of hotel which are horizontal and vertical hotel.

\section{MATERIALS AND METHODS}

The methodology of data collection will determine the suitable procedures systematically and increase the efficiency of collecting data. The preparation for data collection process is explained further in this section to have a great detail in 
every steps involved which are divided into two; observation and collecting data from authorities [11]. The data collections are conducted at two case study areas which are both tourism accommodation premises in Malaysia.

\section{A. Existing Vegetation Specifications}

This research applies a non-participant direct observation in acquiring the data [12]. This method aimed to identify the overall species of existing vegetation at the hotel. Further details of the data needed to calculate Carbon Sequestration Rate or CSR such as the total green area, tree height, diameter, age and quantity are later obtained from the authorities.

\section{B. Inventory and Analysis}

In calculating the total built up areas and green areas of the selected site, the base map of each tourism premises are obtained from the authorities. The bill of quantities (BQ) are also collected to identify the exact quantity of the plant materials and to identify the specifications of vegetation including the overall height and breast height diameter of the existing vegetation to determine the age [13]. After identifying all data needed at both sites, the CSR are calculated for every species of vegetation according to a specific formula [13]. The CSR formulas are as follows in Table I:

TABLE I: CSR FORMULA FOR TREES, SHRUBS, TURF, CREEPER AND CliMBER

\begin{tabular}{|c|c|}
\hline CSR formula for trees and shrubs & CSR formula for turf, creeper \& climber \\
\hline 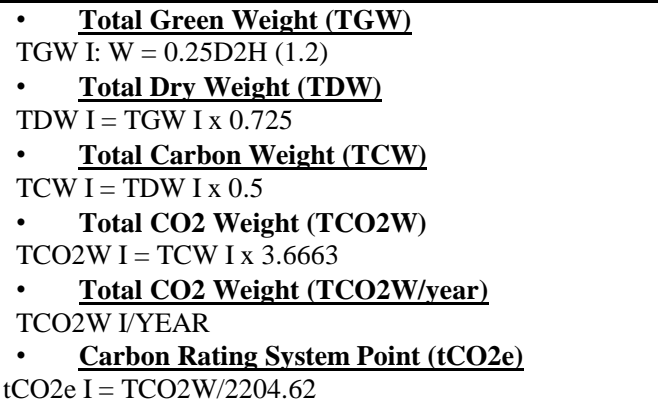 & 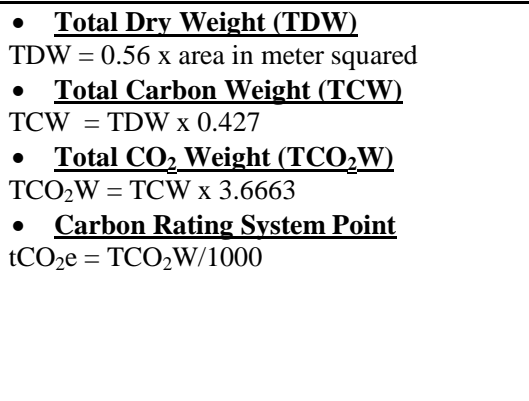 \\
\hline
\end{tabular}

\section{RESULT AND DISCUSSION}

Case Study 1 (Horizontal Hotel): Empayar Muzaffar Hotel, Ayer Keroh, Melaka

Referring to Fig. 1, it shows the visual information about the total built up area and green area of the hotel. The blue color indicates built up area while the green color indicates green area. The summary of those areas can be seen in the Table II below:

Table II showed that the built up area is $90 \%$ while the green area of this hotel are nearly $10 \%$ from the total area. This hotel also was classified as horizontal hotel because the total built up area is more than $30,000 \mathrm{~m}^{2}$ and it has only seven floors all together. The green area of the hotel are included the planting area at the parking lot, planter box and planter pot plants, planting area at water features, lounge and VVIP room and the roof top garden. Empayar Muzaffar Hotel is perceived to have more development as compared to the green spaces. Below are the vegetation list of Empayar Muzaffar Hotel plant materials. The carbon sequestration value for each species of the vegetation was identified as the Table III:

TABLE II: THE SUMMARY OF OVERALL AREAS

\begin{tabular}{l|cc}
\hline & AREA $\left(\mathrm{m}^{2}\right)$ & PERCENTAGE $(\%)$ \\
\hline TOTAL BUILT UP AREA & $31,861.40$ & 90 \\
TOTAL GREEN AREA & $3,529.80$ & 10 \\
TOTAL AREA OF THE & $35,391.21$ & 100 \\
PREMISE & & \\
\hline
\end{tabular}

TABLE III: VEGETATION SPECS OF EMPAYAR MUZAFFAR HOTEL

\begin{tabular}{|c|c|c|c|c|c|}
\hline TREE & & & & & \\
\hline SPECIES & OVERALL HEIGHT/feet & TOTAL DIAMETER /inch & AGE & QTY & $\mathrm{CSR} / \mathrm{tCO}_{2} \mathrm{e}$ \\
\hline 1.Baekea frutescen & 6.56 & $11.81-27.56$ & 28 year & 11 & 5.95 \\
\hline 2.Bucida molineti & $6.56-9.84$ & $11.81-19.69$ & 20 year & 32 & 13.24 \\
\hline 3. Dalbergia cochinchinensis & $6.56-9.84$ & $19.69-27.56$ & 28 year & 26 & 21.09 \\
\hline 4. Plumeria alba & 6.56 & $19.69-27.56$ & 28 year & 5 & 2.70 \\
\hline \multicolumn{6}{|l|}{ PALM } \\
\hline SPECIES & $\begin{array}{c}\text { OVERALL HEIGHT/ } \\
\text { feet }\end{array}$ & TOTAL DIAMETER /inch & AGE & QTY & $\mathrm{CSR} / \mathrm{tCO}_{2} \mathrm{e}$ \\
\hline 1. Cocos nucifera & 9.84 & $3.94-7.87$ & 8 year & 18 & 1.98 \\
\hline 2. Livistonia rotundifolia & $9.84-13.12$ & $3.94-5.91$ & 6 year & 11 & 0.68 \\
\hline 3. Roystonea oleracea & $9.84-13.12$ & $3.94-5.91$ & 6 year & 40 & 2.49 \\
\hline \multicolumn{6}{|l|}{ SHRUB } \\
\hline SPECIES & $\begin{array}{l}\text { OVERALL HEIGHT } \\
\text { /feet }\end{array}$ & TOTAL DIAMETER /inch & AGE & QTY & $\mathrm{CSR} / \mathrm{tCO}_{2} \mathrm{e}$ \\
\hline 1.Muraraya paniculata dwarf & 0.66 & 0.59 & 1 year & 2190 & 0.09 \\
\hline 2.Phyllanthus myrtifolius & 0.66 & 0.79 & 1.5 year & 2320 & 0.17 \\
\hline 3. Cyathea latebrosa & 3.28 & 0.59 & 1 year & 58 & 0.01 \\
\hline 4. Jasminum multiflorum & 1.31 & 0.39 & 1 year & 650 & 0.02 \\
\hline 5. Philodendron selloum & 1.31 & 0.47 & 1 year & 525 & 0.03 \\
\hline 6. Thunbergia grandiflora alba & 0.66 & 0.79 & 1.5 year & 150 & 0.01 \\
\hline 7. Wrightia antidysenterica & 1.31 & 0.79 & 1.5 year & 750 & 0.09 \\
\hline
\end{tabular}


TABLE IV: DISTRIBUTION OF CARBON SEQUESTRATION RATE BY TYPES OF

\begin{tabular}{c|c}
\multicolumn{2}{c}{ PLANTS } \\
\hline TYPE & VALUE \\
& $\left(t C \mathrm{CO}_{2} e\right)$ \\
\hline Trees & 42.98 \\
Palms & 5.15 \\
Shrubs & 0.43 \\
\hline
\end{tabular}

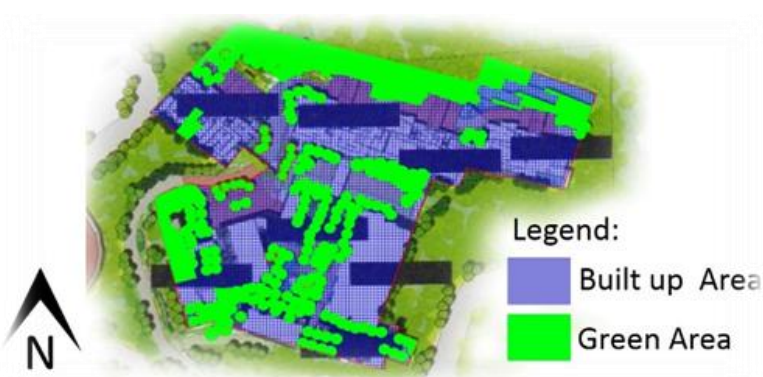

Fig. 1. The Empayar Muzaffar Hotel area.

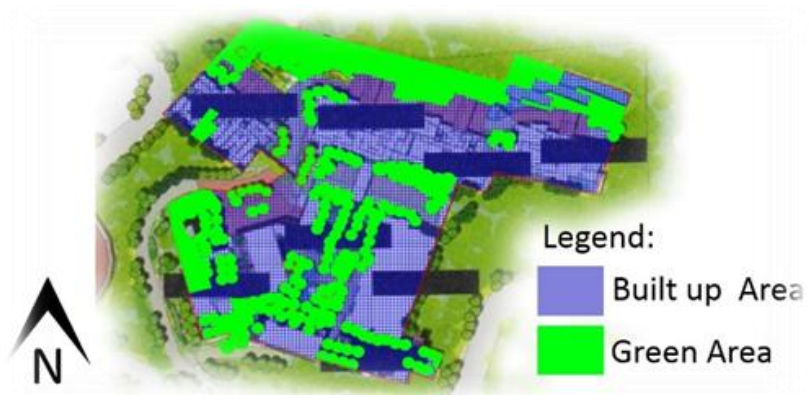

Fig. 2. The I'ON D Element Hotel area.
TABLE V: THE SUMMARY OF OVERALL AREAS

\begin{tabular}{l|cc}
\hline & $\begin{array}{c}\text { AREA } \\
\left(\mathrm{m}^{2}\right)\end{array}$ & $\begin{array}{c}\text { PERCENTAGE } \\
(\%)\end{array}$ \\
\hline TOTAL BUILT UP AREA & $13,613.58$ & 59 \\
TOTAL GREEN AREA & $9,646.42$ & 41 \\
TOTAL AREA OF THE & $23,260.00$ & 100 \\
PREMISE & & \\
\hline
\end{tabular}

From Table III and Table IV, it can be concluded that the highest value that can be sequestrated is from the tree categories. Total carbon sequestration rate among tree species at this hotel is $42.98 \mathrm{tCO}_{2} e$. The number is extremely high if compared to the palm and shrubs categories which are 5.15 $t \mathrm{CO}_{2} e$ and $0.43 t \mathrm{CO}_{2} e$ respectively. At this particular site, the reason trees is the dominant CSR agent is because the trees specification such as age, diameter and height proposed are very much influencing their CSR ability as they have a higher specification compared to other species.

According to Fig. 2 and Table V above, the total green area and built up area of Ion'D Element Hotel is $41 \%$ and $59 \%$ respectively. Since $10 \%$ is the standard allocated green space area reserved for any development, Ion'D Element Hotel illustrated that it has an extra spaces for the green area. The green areas of the hotel are nearly equal to the built up area. Below are the inventory and analysis of vegetation details at I'on D Element Hotel, Genting.

Case Study 2 (Vertical Hotel): ION'D Element Hotel, Genting, Pahang

TABLE VI: THE VEGETATION SPECS OF I'ON D ELEMENT

\begin{tabular}{|c|c|c|c|c|c|}
\hline TREE & & & & & \\
\hline SPECIES & OVERALL HEIGHT/feet & TOTAL DIAMETER /inch & AGE & QTY & $\mathrm{CSR} / \mathrm{tCO}_{2} \mathrm{e}$ \\
\hline 1.Baekea frutescen & 6.56 & 2.95 & 8 year & 16 & 0.06 \\
\hline 2.Tabebuia argantaea & 6.56 & 2.95 & 8 year & 2 & 0.01 \\
\hline 3. Brownea ariza & 6.56 & 2.95 & 8 year & 10 & 0.21 \\
\hline 4. Nageia rumphii & 6.56 & 2.95 & 8 year & 6 & 0.06 \\
\hline 5. Cratoxyllum cochinensis & 6.56 & 2.95 & 8 year & 9 & 0.09 \\
\hline 6. Pteleocarpa lamponga & 9.84 & 2.95 & 8 year & 5 & 0.08 \\
\hline 7. Eucalypthus camaldulensis & 9.84 & 2.95 & 8 year & 9 & 0.14 \\
\hline \multicolumn{6}{|l|}{ SHRUB/FERN } \\
\hline SPECIES & OVERALL HEIGHT/feet & TOTAL DIAMETER /inch & AGE & QTY & $\mathrm{CSR} / \mathrm{tCO}_{2} \mathrm{e}$ \\
\hline 1. Canna hybrid & 1.97 & 15.00 & 1.5 year & 75 & 0.67 \\
\hline 2. Habranthus sp. & 0.98 & 1.18 & 1.2 year & 180 & 0.02 \\
\hline 3. Cyathea latebrosa & 1.48 & 3.94 & 1.2 year & 375 & 9.16 \\
\hline 4. Loropetalum chinese & 1.48 & 1.18 & 1.2 year & 125 & 0.05 \\
\hline 5. Philodendron selloum & 0.33 & 6.00 & 3 year & 350 & 0.75 \\
\hline 6. Costus amazonicus & 0.33 & 0.78 & 0.8 year & 250 & 0.01 \\
\hline 7. Penisettum rubrum & 0.98 & 1.10 & 1.2 year & 130 & 0.28 \\
\hline 8. Lantana camara & 0.33 & 1.97 & 2 year & 300 & 0.03 \\
\hline 9. Hippestrum amaryllis & 0.33 & 2.75 & 2.8 year & 250 & 1.00 \\
\hline 10 Arundina $s p$ & 0.33 & 2.36 & 2.4 year & 450 & 0.15 \\
\hline 11. Calathea Wilson princep & 0.33 & 5.12 & 2.5 year & 950 & 1.49 \\
\hline 12. Angelonia biflora & 0.33 & 1.97 & 2 year & 250 & 0.06 \\
\hline 13. Sterlitzia reginae & 0.33 & 13.00 & 1.3 year & 200 & 2.02 \\
\hline \multicolumn{6}{|c|}{ GROUNDCOVER/CREEPER/CLIMBER } \\
\hline SPECIES & OVERALL HEIGHT/feet & TOTAL AREA/m $\mathbf{m}^{2}$ & AGE & QTY & $\mathrm{CSR} / \mathrm{tCO}_{2} \mathrm{e}$ \\
\hline 1. Axonapus compresus & 0.16 & 1267.07 & - & 2850 & 0.17 \\
\hline 2.Zoysia matrella & 0.16 & 570.07 & - & 900 & 0.05 \\
\hline 3. Vernonia elliptica & - & 206.68 & - & 3000 & 0.15 \\
\hline 4. Pogonantherum paniceum & 0.16 & 96.85 & - & 475 & 0.03 \\
\hline 5. Vallaris glabra & - & 82.54 & - & 300 & 0.07 \\
\hline
\end{tabular}

From Table VI and Table VII, it can be depicted that total carbon sequestration rate that occurs among shrubs species at this hotel is the highest $\left(15.0 \mathrm{tCO}_{2} \mathrm{e}\right)$. The number is extremely high if compared to the trees and groundcovers categories which are $2.17 \mathrm{tCO}_{2} \mathrm{e}$ and $1.69 \mathrm{tCO}_{2} \mathrm{e}$ respectively. At this particular area shrubs category is dominant CSR agent 
because the numbers of shrubs proposed are enormous compared to other plant types. Therefore the numbers of plant material proposed is also a major contributor to CSR percentage.

Based on the findings above, each types of vegetation are classified according to its grades based on the ability in sequestering carbon as detailed in Table VIII. This method somehow enables to identify the prime contributor in CSR of the hotel. The classifications are as follows in Table VIII.
TABLE VII: DISTRIBUTION OF CARBON SEQUESTRATION RATE BY TYPES OF

\begin{tabular}{c|c}
\multicolumn{2}{c}{ PLANTS } \\
\hline TYPE & VALUE $\left(\mathrm{tCO}_{2} e\right)$ \\
\hline Trees & 2.17 \\
Palms & 0 \\
Shrubs & 15.00 \\
Groundcover & 1.69 \\
Creeper & 0.18 \\
Climber & 0.07 \\
Ferns & 0.40 \\
\hline
\end{tabular}

TABLE VIII: CARBON SEQUESTRATION RATE GRADES

\begin{tabular}{|c|c|c|}
\hline \multicolumn{3}{|l|}{ TREE } \\
\hline Grade $1>2.0 \mathrm{tCO}_{2} \mathrm{e}$ & Grade 2 $=0.1-2.0 \mathrm{tCO}_{2} \mathrm{e}$ & Grade $3<0.1 \mathrm{tCO}_{2} \mathrm{e}$ \\
\hline Dalbergia cochinchinensis* & Brownea ariza & Pteleocarpa lamponga \\
\hline Bucida molineti* & Juniperus chinensis & Agathis borneensis \\
\hline Baeckia futescens* & Pinus caribea & Casuarina nobilis \\
\hline \multirow[t]{4}{*}{ Plumeria alba* } & Spathodea campanulata & Nageia rumphii \\
\hline & Eucalypthus camaldulensis & Cratoxyllum cochinensis \\
\hline & & Baeckia futescens \\
\hline & & Tabebuia argantaea \\
\hline \multicolumn{3}{|l|}{ PALM } \\
\hline Grade $1\left(1.8-2.6\right.$ tCO $\left._{2} \mathrm{e}\right)$ & Grade $2\left(0.9-1.7 \mathrm{tCO}_{2} \mathrm{e}\right)$ & Grade $3\left(0-0.8 \mathrm{tCO}_{2} \mathrm{e}\right)$ \\
\hline Roystonea oleracea* & Cocos nucifera* & Livistonia rotundifolia* \\
\hline \multicolumn{3}{|l|}{ SHRUB } \\
\hline Grade $1>1.0 \mathrm{tCO}_{2} \mathrm{e}$ & Grade $2=0.5-1.0+\mathrm{CO}_{2} \mathrm{e}$ & Grade $3<0.5 \mathrm{tCO}_{2} \mathrm{e}$ \\
\hline Canna hybrid & Philodendrum selloum * & Habranthus sp. \\
\hline Calathea Wilson princep & & Loropetalum chinese \\
\hline Sterlitzia reginae & & Penisettum $s p$. \\
\hline \multirow[t]{10}{*}{ Cyathea letebrosa ${ }^{*}$} & & Lantana camara \\
\hline & & Hippestrum amaryllis \\
\hline & & Arundina $s p$. \\
\hline & & Angelonia biflora \\
\hline & & Philodendron \\
\hline & & Muraraya paniculata dwarf* \\
\hline & & Phyllanthus myrtifolius* \\
\hline & & Jasminum multiflorum* \\
\hline & & Thunbergia grandiflora alba* \\
\hline & & Wrightia antidysenterica* \\
\hline \multicolumn{3}{|l|}{ FERN } \\
\hline Grade $1>0.0005 \mathrm{tCO}_{2} \mathrm{e}$ & Grade $2=0.0005 \mathrm{tCO}_{2} \mathrm{e}$ & Grade $3<0.0005 \mathrm{tCO}_{2} \mathrm{e}$ \\
\hline Nepenthes gracilis & Neprolepsis biserrata & Neprolepsis aculifolia \\
\hline \multicolumn{3}{|c|}{ GROUNDCOVER/CLIMBER/CREEPER } \\
\hline Grade $1>0.05 \mathrm{tCO}_{2} \mathrm{e}$ & Grade $2=0.05 \mathrm{tCO}_{2} \mathrm{e}$ & Grade $3<0.05 \mathrm{tCO}_{2} \mathrm{e}$ \\
\hline Vernonia elliptica & Zoysia matrella & Pogonantherum paniceum \\
\hline \multicolumn{3}{|l|}{ Vallaris glabra } \\
\hline Axonapus compresus & & \\
\hline
\end{tabular}

As shown in Table VIII above, the species marked with (*) are the species existed in Empayar Muzaffar Hotel and those without are in Ion'D Element Hotel. It is apparent that the variety of plants used in the hotel which consist of mixture of grades in sequestering carbon. Thus it can be suggested that the CSR of a tree does not solely depend on the species itself but the specifications of the tree. As for groundcovers, creepers, climbers and ferns, the CSR are lesser compare to tree when counted as a unit.

These findings suggest that, although Ion'D Element Hotel allocated more percentage of green areas in the hotel, the total CSR for the hotel is much lesser than that of Empayar Muzaffar Hotel's. Although Ion'D Element Hotel has much more variety of vegetation types, the CSR is still less to Empayar Muzaffar Hotel which has only three types of vegetation; trees, palms and shrubs. Interestingly, the most CSR in Ion'D Element Hotel is by shrubs but amounts only up to $15 \mathrm{tCO}_{2} \mathrm{e}$ while Empayar Muzaffar Hotel's most CSR is done by trees which sequester approximately $43 \mathrm{tCO}_{2} \mathrm{e}$. The difference between the ability of existing tree in both hotels to sequester carbon differs greatly although when referring back to Table VIII there are similarities in some of the tree species due to different grades of the trees selection. As the existing trees are older, the greater carbons are being absorbed and stored. Similarly, if the selection of shrub in horizontal design hotel is similar to vertical design hotel by using the first grade list, the optimum rate of CSR could be achieved.

TABLE IX: COMPARISON OF CSR FOR VERTICAL AND HORIZONTAL HOTEL

\begin{tabular}{c|cc}
\multicolumn{3}{c}{ DESIGN BASED ON PLANT MATERIAL TYPES } \\
\hline TYPE & $\begin{array}{c}\text { Vertical Design } \\
\text { Hotel }\end{array}$ & $\begin{array}{c}\text { Horizontal Design Hotel } \\
\text { Tree }\end{array}$ \\
Palm & 2.17 & 42.98 \\
Shrub & 0 & 5.15 \\
Groundcover & 15.00 & 0.43 \\
Creeper & 1.69 & 0 \\
Climber & 0.18 & 0 \\
Ferns & 0.07 & 0 \\
TOTAL CSR & 0.40 & 0 \\
\hline
\end{tabular}




\section{CONCLUSION}

In can be concluded that among the factors influencing the total CSR of the hotels regardless horizontal or vertical design hotel are due to the followings:

1) Vegetation specifications (tree height, diameter, and age)

2) Type of plant materials group (Tree, palm, shrub)

3) Quantity and quality of plant materials.

4) Percentage of green area

5) Landscape design

\section{ACKNOWLEDGMENT}

The authors would like to thanks Ministry of Higher Education (MOHE) and International Islamic University Malaysia (IIUM) for the Research Grant NRGS13-002-0002.

\section{REFERENCES}

[1] C. Lopez, "A manual for the family PPSESWA Malaysia," PPSEAWA, p. $4,1999$.

[2] M. Hussain, M. I. Javaid, and P. R. Drake, "An econometric study of carbon dioxide emissions, energy consumption, and economic growth of Pakistan," International Journal of Energy Sector Management, vol. 6, no. 4, pp. 518-533, 2012.

[3] S. Mangalassery, D. Dayal, S. L. Meena, and B. Ram, "Carbon sequestration in agroforestry and pasture systems in arid Northwestern India," Current Science, vol. 107, no. 8, pp.1290-1293, 2014.

[4] S. A. Malaysia, Malaysian Environment in Crisis, Pulau Pinang, Jutaprint, pp. 140-141, 2006

[5] T. Wiedman and J. Minx, "The carbon trust helps UK businesses reduce their environmental impact," Ecological Economic Research Trend, Library of Congress Cataloging-In-Publication Data, Nova Science Publisher, pp.1-11, 2007.

[6] U. Singh, "Carbon capture and storage: An effective way to mitigate global warming," Current Science, vol. 105, no. 7, pp. 914-922, 2013.

[7] S. A. Rackley, "Carbon capture and storage," United States of America, Butterwoth-Heinemann Publication, pp. 42-49, 2010.

[8] I. E. Henson, "A modelling package for estimating carbon sequestration, greenhouse gas emission and carbon balance associated with oil palm cultivation in Malaysia, Kuala Lumpur," Malaysiam Palm Oil Board, pp. 4-10.

[9] E. Sundquist, R. Burruss, S. Faulkner, R. Gleason, J. Harden, Y. Kharaka, L. Tieszen, and M. Waldrop, "Soil carbon sequestration to mitigate climate change," Encyclopedia of Energy, pp. 289-298, 2004.

[10] Q. Wang, P. Zhou, S. Ge, and Z. Zhao, "An international comparison of carbon dioxide emission performance using the nonparametric metafrontier approach," Pol. J. Environ. Stud., vol. 23, no. 3, pp. 923-931, 2013.

[11] European Commission. Carbon footprint - What it is and how to measure it. [Online]. Available: http://lct.jrc.ec.europa.eu/

[12] K. D. Kanwalroop, "The role of carbon offsets in achieving carbon neutrality: an exploratory study of hotels and resorts," International Journal of Contemporary Hospitality Management, pp. 37-45, 2014.

[13] M. Mitrovic and A. Malone, "Carbon capture and storage (CCS) demonstration projects in Canada," Energy Procedia, vol. 4, pp. 5685-5691, 2011.

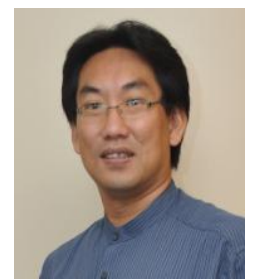

Rashidi Othman obtained his B.Sc. in horticulture from Universiti Pertanian Malaysia, Kuala Lumpur, Malaysia. He then obtained his MSc. (plant tissue culture) in 2001 from University of Malaya, Kuala Lumpur, Malaysia and eventually completed his Ph.D (biochemistry and genetics of carotenoids) in 2010 from Lincoln University, New Zealand. He is currently a certified horticulturist at the Department of Landscape Architecture, KAED, IIUM. His research interests include horticulture, landscape ecology, environmental sciences, and halal Science.

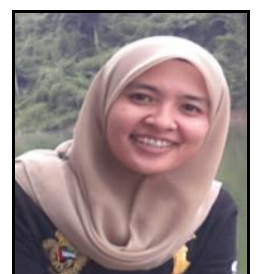

Siti Zubaidah Abu Kasim is a Ph.D. candidate of the Department of Landscape Architecture, Kulliyyah of Architecture and Environmental Design, International Islamic University, Malaysia. She earned her first degree in bachelor of landscape architecture from the International Islamic University Malaysia in 2007. She then pursued her master's degree at the same university in 2011 majoring in master of science in built environment. At present, she is interested in any research topic pertains to the application of plant materials as carbon sequestration agent in hotels and resorts. 